\title{
Expansive Learning of Preservice Teachers Teaching Sustainable Development during Their Practicum
}

\author{
Anthoula Maidou ${ }^{1, *}$, Katerina Plakitsi ${ }^{1} \&$ Hariton M. Polatoglou ${ }^{2}$ \\ ${ }^{1}$ Department of Early Childhood Education, University of Ioannina, Ioannina, Greece \\ ${ }^{2}$ School of Physics, Aristotle University of Thessaloniki, Thessaloniki, Greece \\ *Correspondence: Department of Early Childhood Education, University of Ioannina, Greece. Tel: 30-694-848-7388. \\ E-mail: anthoula.maidou@gmail.com
}

Received: March 16, 2020

doi:10.5430/wje.v10n2p181

\author{
Accepted: April 15, 2020 \\ Online Published: April 22, 2020 \\ URL: https://doi.org/10.5430/wje.v10n2p181
}

\begin{abstract}
Education for Sustainable Development (ESD) is a complex and multifaceted subject, including many aspects, environmental, societal, and financial. It is not a set of knowledge, which can be learned, because it is an evolving subject and in addition solutions that are successfully applied at specific locations might fail elsewhere. ESD should make students aware of the problems humankind is facing and encourage them to become active citizens. Thus, people must also have positive attitudes towards sustainability issues. In this study, we will present the results of a teaching intervention (TI) leading to a system of two expansive learning cycles. For the TI we used the topic of houses, which are a social construct, an economic entity, and have environmental influence. The researcher, an architect had to transform her knowledge to prepare the TI, thus starting an expansive learning cycle which was influenced by the outcome of the TI. The preservice teachers, who decided to use the topic of houses during their internship started their expansive cycle, which again influenced the researchers' learning cycle. In this study, we will present the results of the TI and the implementation of the preservice teachers' teachings of SD during their practicum. The preservice teachers reflected on their teachings in their written reports, which were used to analyze how preservice teachers chose to apply the topic 'houses' during their internship.
\end{abstract}

Keywords: teaching intervention, expansive learning cycle, education for sustainable development, Socrates' house, bioclimatic architecture

\section{Introduction}

\subsection{Education for Sustainable Development}

Humankind is currently facing urgent problems. To name some, climate change (Anderson, 2013; Mochizuki \& Bryan, 2015) with ever-increasing extreme weather conditions, accumulation of plastic waste (Burmeister \& Eilks, 2012; Kerscher, 2019), plastic debris entering the food chain at an unprecedented rate (Waring, Harris \& Mitchell, 2018), pandemics, migration problems, access to education, gender equality, etc. These problems require high priority in dealing with, in a collective effort by all, governments, stakeholders, and individuals. However, to achieve change, people must acquire knowledge in combination with positive attitudes and values to take action (Gayford \& Dillon, 1995). It must be noted, however, that ESD is not a set of knowledge that can be learned (McKeown, 2002; McKeown \& Hopkins, 2003), since solutions that have been successfully implemented in one place, might fail at other location because of different local conditions. It is furthermore an ongoing subject (McKeown \& Hopkins, 2003). Therefore, ESD helps rather to educate informed and critical thinking democratic citizens, willing to contribute to all three dimensions of ESD as a whole, namely the environment, society, and economy.

Teachers can support change in people's attitudes and values through their teachings in formal and informal educational settings and at all educational levels (Bekessy et al., 2003; Christie, Miller, Cooke, \& White, 2013; Cortese \& Hattan, 2010; Holdsworth et al., 2008; UNESCO, 2005a; WCED, 1987). There is an urgent need to include lessons on sustainable development (SD) at all levels of education starting with preschool education if we want to ensure a quality life for future generations. Future teachers should, therefore, be trained during their studies (Bekessy et al., 2003; Christie et al., 2013; Cortese \& Hattan, 2010). SD is a concept that is difficult to define and 
furthermore difficult to teach (McKeown, 2002). SD topics can either be integrated into all courses (McKeown, 2014) or be taught as a separate subject.

To be able to teach about ESD, teachers need to have subject and pedagogical knowledge (Summers, Corney, \& Childs, 2003). The suitable teaching approaches to ESD are student-centered (McNaughton 2012; Tomas, Girgenti, \& Jackson, 2017; UNESCO, 1992) experiential, participatory (Lysgaard \& Simovska, 2016), praxis-orientated, place-based, interdisciplinary (UNESCO, 1992; Saka \& Sahintürk, 2013), inquiry-based and transformational (Biasutti, 2015; Christie et al., 2013; Corney \& Reid, 2007; Tomas, Girgenti, \& Jackson, 2017). These methods promote changes in behaviors and attitudes and relate to knowledge and to processes because these methods teach learners how to think (Biasutti, 2015). These pedagogies are student-centered, and apply teaching approaches as fieldwork, role plays, debates, reflective accounts, case studies, and critical reading and writing activities inquiry-based learning, experiential learning and action competence (Christie et al., 2013; Cotton \& Winter, 2010; Garrard, 2010; Sterling, 2010; UNESCO, 2012;). ESD promotes competencies like critical thinking, imagining future scenarios, and making decisions in a collaborative way. Therefore, ESD requires far-reaching changes in the way education is often practiced today (UNESCO, 1992).

\subsection{Internship of Pre-Service Teachers}

It is widely believed that pre-service teachers learn to become teachers through their university studies and workplace experiences (Darling-Hammond, 2012). Many scholars suggest that school-based training is the most beneficial, authentic, or practical aspect of teacher education (Allen, 2009, Campbell-Evans \& Maloney, 1997; Le Cornu \& Ewing, 2008; Smith \& Lev-Ari, 2005; White, Bloomfield, \& Le Cornu, 2010; White \& Forgasz, 2016) because it enables pre-service teachers to combine theory and practice, and in this way develop knowledge and skills as part of a larger community of educators and co-learners (Goodnough et al., 2009). The practicum appears internationally and repeatedly as a significant component of initial teacher education programmes (Ferrier-Kerr, 2009; Graham, 2006; Haigh \& Ward, 2004). It is considered a bridge between theory and practice in the learning of teaching and the place where pre-service teachers develop their personal teaching competence (Darling-Hammond, 2006). Pre-service teachers often identify the practicum as the most powerful aspect for their preparation as teachers (Graham, 2006; Wilson, Floden, \& Ferrini-Mundy, 2002).

Murray, McNamara \& Jones, (2014) describe workplace learning as highly complex and multi-layered, taking place in formal or informal, structured or unstructured programmes, leading to good, bad and indifferent outcomes. "Some of these may be planned but others are quite unforeseen and unintended in their forms and in their short- and long-term effects. ... learning at and through work is, inevitably, influenced by the structural and socio-cultural factors inherent in the workplace and in the broader professional, socio-economic and cultural contexts in which it occurs" (Murray, McNamara \& Jones, 2014, p. 295). Achieving the integration of university teachings and professional experience is not always easy, requiring a coherent and shared conception of teaching and learning by academics and school-based teachers (Deed, Cox, \& Prain, 2011; Hammerness, 2006; Pridham, Deed, \& Cox, 2013).

The practicum is nevertheless not always described as a positive experience. Some preservice teachers described it as a time to tolerate and consent, or as an experience that is inconsistent and disempowering (Rorrison, 2006). It is often experienced as a dissociation between the demands of the schools and their teacher education courses (Trent \& Lim, 2010). This dissociation and the contradiction of experiencing simultaneously lack of support and lack of autonomy leads the pre-service teachers to the feeling that they have no power or control over themselves or the situation (Dobbins, 1996). In addition, schools are not very receptive to new teachers and their learning needs (El Kadri \& Roth, 2015). Tensions may also form because of the power relations between the pre-service teacher, school-based teacher, and teacher educator (Patrick, 2013). Furthermore, during their practicum the pre-service teachers must develop practical knowledge about teaching and learning while balancing diverse and contradictory suggestions, approaches and frameworks from prior experience, teacher educators, school-based teacher, other teachers and peers (Deed et al., 2011; Griffiths \& Guile, 2004; Pridham, Deed, \& Cox, 2013).

Murray, McNamara, and Jones (2014) consider the notion of the school workplace, as the only place in which pre-service teachers can develop or extend their knowledge as simplistic, since "such constructions of teachers' learning as a superficial linear process of improvement, directly related to very narrow constructions of 'practice' which need to impact positively and almost immediately on pupil learning" (p. 298). Furthermore, in this way, other learning settings as universities, cross-professional territories, and virtual spaces are marginalized. They also challenge strongly the belief that knowledge is effectively acquired through transmission and apprenticeship. They rather support Engeström's (2001) theory of workplace learning where learning is essentially expansive, ill-defined, complex, and changeable in nature. 


\subsection{Theoretical Framework}

\subsubsection{Expansive Learning}

Expansive learning refers to learning in which learners are involved in the construction and implementation of a new, broader, and more complex object and concept for their activity. Expansive learning theory plays a key role in learning communities, transforming and creating culture, and shaping theoretical concepts (Rantavuori, Engeström \& Lipponen, 2016). Through expansive learning, students construct a new object and concept for their collective activity and apply this new object in practice by merging the designing, planning, and the educational process (Engeström \& Sannino, 2010; Rantavuori, Engeström, \& Lipponen, 2016).

Expansive learning theory is an object-oriented theory, namely, the object is both raw material and the future orientation of the activity (Rantavuori, Engeström \& Lipponen, 2016). The object is the real driver of the activity; thus, the motivation is not in the individual subjects but in the transformation and expansion of the object. Furthermore, it is based on the dialectics of ascending from the abstract to the concrete (Engeström \& Sannino, 2010), thus enabling the understanding of the essence of an object by locating and theoretically reproducing the logic of its development, through tracing its historical formation by the appearance and resolution of its internal contradictions (Engeström \& Sannino, 2010; Rantavuori, Engeström, \& Lipponen, 2016).

Expansive learning is a gradual process involving seven phases called learning actions. These actions are an expansive cycle or spiral. An ideal sequence of learning actions in an expansive cycle can be described as follows (Engeström, 2001, Engeström \& Sannino, 2010): 1. Questioning, 2. Historical and empirical analysis, 3. Modeling the new solution, 4. Examining the new model, 5. Implementing the new model, 6. Reflecting on the process, and 7. Consolidating the new practice. This model is an ideal tool for analyzing the components of expansive learning. Real cycles of expansive learning do not necessarily follow the order presented in the theoretical model. Although this learning cycle is often applied to large systems (Engeström, 2000, 2001), it can also be used at a micro level, such as to pre-service teachers' professional learning (Sorensen, 2014).

The expansive learning model is useful when trying to understand open learning processes in which the problem and its solution are not predetermined and participants need to learn something that 'does not yet exist', that is, to produce and adopt culturally new practices and knowledge. While expansive learning has been studied in relatively long-term transformations and interventions, large-scale cycles include many smaller learning cycles (Engeström \& Sannino, 2010). Such a small cycle can take place in an intensive meeting of a group tasked with analyzing and resolving a problem important for the development of its overall activity (Engeström, 2008).

The cycle of expansive learning is not a universal formula - one probably never finds a concrete collective learning process which purely follows the ideal-typical model. In addition, learning processes are never purely expansive (Rantavuori, Engeström, \& Lipponen, 2016). They contain both expansive and non-expansive phases and deviations from the scope of the activity (Engeström et al., 2013). For expansive learning to occur a new expanding object must emerge. If such a new object is not developed, the learning action may be identified as non-expansive (Rantavuori, Engeström, \& Lipponen, 2016).

According to Engeström $(2001,2016)$, the driving force of change and development in activity systems are internal contradictions which are fundamental tensions and misalignments in the structure, that typically manifest themselves as problems, ruptures, and breakdowns in the functioning of the activity system (Virkkunen \& Kuutti 2000). These contradictions urge subjects to find new solutions to achieve the goals of the intended activity (Brown \& Roth, 2002), resulting in expansive transformation and new forms of the activity. Such contradictions are significant for the formation of the teacher's identity and professional development especially in the process of learning to teach in the classroom by pre-service teachers (Engeström \& Sannino, 2010; Gan \& Lee, 2016; Rantavuori, Engeström, \& Lipponen, 2016; Smagorinsky et al., 2004). Contradictions within the elements of an activity system are called primary contradictions, while contradictions between the elements are considered as secondary contradictions. In addition, tertiary contradictions may appear between a newly established mode of activity and remnants of the previous activity, and quarternary contradictions between a newly reorganized activity system and its neighboring activity systems (Engeström and Sannino 2010).

\subsubsection{Thematic Analysis}

Thematic analysis is a widely used qualitative research method despite of it being poorly defined and rarely acknowledged (Braun \& Clarke, 2006; Roulston, 2001). Braun and Clarke (2006) and Nowell, Norris, White, and Moules (2017) argue that thematic analysis is a qualitative research method that can be widely used across a range of epistemologies and research questions. It is a method for identifying, analyzing, organizing, describing, and reporting 
themes found within a data set (Braun \& Clarke, 2006). One of the benefits of thematic analysis is its flexibility, which can potentially provide a rich and detailed, yet complex, account of data (Braun \& Clarke, 2006). Thematic analysis is also useful for summarizing key features of a large data set, offering the possibility to take a well-structured approach to data coding (King, 2004).

\subsection{Our Contribution}

We believe that ESD should be taught at all educational levels, starting with pre-school education and continue with life-long learning.

We used a questionnaire to inquire about the knowledge, perceptions, and attitudes towards SD of the pre-service teachers of the Early Childhood Education Department of the University of Ioannina (Maidou, Plakitsi, \& Polatoglou, 2019a). This questionnaire consisted of two sections: knowledge, perception, and attitudes towards ESD and the second part inquires on the knowledge of heat transfer issues from everyday life, materials' properties (thermal conductivity, thermal insulation, heat capacity), thermal behavior of building materials, and the morphology and functionality of traditional buildings in Greece (Maidou, Plakitsi, \& Polatoglou, 2016).

The main findings of the questionnaire showed that about $47 \%$ of students consider their knowledge of SD issues to be moderate, about $28 \%$ low, and $11 \%$ inadequate. In addition, a high percentage of the participants (about $64 \%$ ) had never ESD or Environmental Education (EE) courses during their studies. When asked about their attitude towards sustainability issues, most (around 70\%) responded that they thought it was important to care about sustainability, but only $12 \%$ said that they were interested and contributing wherever they can, while almost $12 \%$ stated that they do not know what the sustainability problems are.

Moreover, our findings showed that most pre-service teachers do not know about the three dimensions of SD, since $95 \%$ responded that ESD includes environmental issues, about $50 \%$ social problems, while only $34 \%$ mentioned economic issues. In addition, a clear majority stated that they fully agree (35\%) or agree $(42 \%)$ that ESD should be included in future teachers' curricula. When asked if they think they need more training on SD issues, $78 \%$ agreed (32\% very much, and $46 \%$ much).

For all the above-mentioned reasons we decided to conduct TIs on SD. The activities of the TIs were designed and analyzed using the Cultural-Historical Activity Theory (Engeström, 1987). To evaluate the outcome of the TIs we utilized the same questionnaire immediately after the TI and compared the pre- and post-test results. The TIs started during the academic year 2014-15 as a pilot, and during the following 3 years we experimented with the activities, experiments, and teaching approaches conducting expansive learning cycles on how to teach preservice teachers about SD. We found the outcome of the year 2017-2018 satisfactory. Although the TIs and the outcomes of the TI during 2017-18 will soon be submitted for publication (Maidou, Plakitsi, \& Polatoglou, to be submitted), we will briefly describe some of the results of the post-test results as an indication of the improvement of the pre-service teachers' knowledge, perceptions and attitudes towards ESD. After the TIs $98.4 \%$ of the students recognized environmental issues as aspects of SD, $89.8 \%$ societal issues, and $85.2 \%$ financial, exhibiting a profound improvement of the knowledge of the dimensions of ESD. Enhancement of knowledge on SD was also evident from answers to separate statements concerning the environment, society and economy, with a 5-point Likert scale, where the total score from $47.8 \%$ (for agree and strongly agree) of the pre-test went up to $83.4 \%$ for the post-test results. Development of their perceptions on the importance of SD for them could also be observed - from $62.6 \%$ in total for the pre-test results to $78.1 \%$ for the post-test results. Their attitudes towards SD also improved with even more pre-service teachers acknowledging the importance of ESD for their teachings ( $79.5 \%$ before and $90.6 \%$ after the TIs) and their role as future teachers to influence their students to become responsible citizens $(70.2 \%$ before and $87.5 \%$ after).

These TIs served as a first stimulus for the pre-service teachers, aiming to motivate and engage them with SD. As the main topic to introduce students to SD we used houses, since houses are a very familiar subject to all, of any age and cultural background. Furthermore, houses can be analyzed through all dimensions of SD, namely, they have environmental and economic influence, and bear cultural and symbolic meaning. The pre-service teachers had to conduct teachings during their internship in pre-schools, where they were placed in pairs. For the teachings, they could choose among several subjects to apply during their practicum in the field of Sciences. During the academic year 2017-2018, we gave the preservice teachers the ability to apply ESD as one of the possible themes during their practicum. Here, we will report on the outcome of the pre-service teachers who chose the subject ESD.

In this study, we will focus on the expansive learning cycles performed by the pre-service teachers. The central question was: How do pre-service teachers design, implement their teaching activities about SD to the pre-school 
pupils during their internship. More precisely:

- Do the pre-service teachers cover all three dimensions of ESD in connection with houses?

- Do they use interactive teaching approaches?

- Did the practicum serve as a learning cycle for the pre-service teachers?

\section{Method}

\subsection{Expansive Learning Cycles}

Activity theory can be applied as a framework to understand how pre-service teachers describe the problems they encounter and what tools they use to tackle the difficulties. The subjects of this analysis are the pre-service teachers who participated in the practicum. Their experiences and activities were influenced by the sociocultural context where the activities occurred. The object of the pre-service teachers' internship is to teach about ESD to young pupils, using suitable teaching scenarios and teaching approaches for their pupils. The tools they use to achieve the object of the activity are teaching scenarios and teaching approaches. The community members that supported the pre-service teachers are the cooperating pre-schools and schoolteachers on one hand and the university teachers of the Early Childhood Department on the other hand. The rules underlying the pre-service teachers' participation in the practicum included the teaching practices of the hosting school, and the university requirements of the teacher training course. The division of labor refers to the responsibilities the pre-service teachers take over during their practicum from the schoolteacher, but since they are working in pairs, it refers also to the division of labor among them, and additionally, to the relationship between the pre-service teachers and the pupils. The outcomes of the pre-service teachers' practicum should be teaching competencies and acquaintance with the pupils' diversity (Cohen, Hoz \& Kaplan, 2013).

In this study, we describe the expansive cycles that occurred for the pre-service teachers as a result of their willingness to teach about ESD using houses as the key issue. Their actions formed several learning cycles during the preparation and application of their teaching scenarios, that could be potentially expansive (Engeström \& Sannino $2010,11)$. These learning cycles gave direction and drive to their new practice - containing working methods and learning strategies (Postholm, 2014), and became part of the expansive learning process.

\subsection{Participants}

The participants were pre-service teachers in their $6^{\text {th }}$ or $8^{\text {th }}$ semester. Since they could choose among three subjects as the theme of their practicum in the field of Science Education, we can presume that all students were highly interested in the subject SD and considered it important for themselves and the pupils. 31 pre-service students chose to apply ESD during their practicum in different pre-primary schools. The preservice teachers were placed in pairs although one group consisted of 3 students and one pair experienced difficulties in their collaboration and therefore these two students handed in their own report - hence, we got 16 reports of their practicum experience.

\subsection{Data and Analysis of Data}

In this presentation, we will focus on the expansive miniature cycles of the pre-service teachers. We use the reports from their internship, where they described what they did, how they did it, their evaluation of the activities they applied, mostly accompanied by photographic documentation. Furthermore, some students handed in recordings of the discussions they had with the pupils and pictures of the activities and the outcomes of the pupils activities. All these data, e.g. text, pictures, and audio were used to understand the process of the expanding miniature cycles the pre-service teachers initiated.

\subsection{Thematic Analysis}

To analyze the reports, we used Thematic Analysis (Braun \& Clarke, 2006; Nowell, Norris, White \& Moules, 2017). Our analysis followed a 'theoretical' thematic analysis (Braun \& Clarke, 2006) driven by our interest in the way the preservice teachers approached the design and conduction of their teaching activities, the means they used for it and the teaching approaches, as well as their evaluation of the outcomes of their activities, the difficulties they experienced and the feedback they gave from their placement experience. 


\section{Results}

\subsection{Teaching Approaches}

All pre-service teacher groups used interactive teaching approaches. They employed group discussions on specific topics, allowing pupils to describe their experiences, using words or paintings, or other means of expression as pantomime or theatrical representations or games. Many groups used cultural artifacts like songs, paintings, pictures, etc. to introduce houses. The most used tool by all preservice teacher groups were discussions with the pupils or asking the pupils to describe something. In this way, the preservice teachers intended to get to know the pupils and to help them to develop their communication skills. One group added also that speaking and describing things 'allows the pupils to express themselves, and build on their existing knowledge' (Christie, George). Drawing and painting activities were also used by all preservice teachers, while some constructed with the pupils simple models of houses. They applied group work, role play, experimentation in small groups, field work, etc. The students created altogether 145 activities for the pupils.

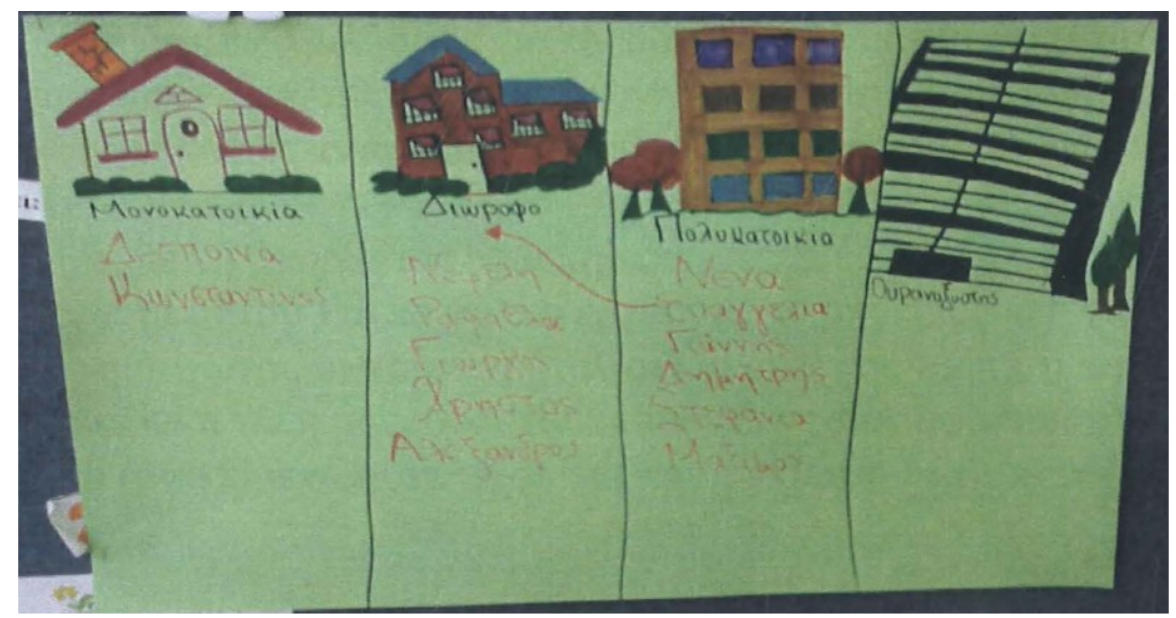

Figure 1. Pupils Were Asked to Describe the Type of Their House. The Pre-Service Teachers Added the Name of the Pupils to the House-Type, According to the Description

Pupils were mostly asked to speak about something or describe it. Hereby the pupils were engaged in activities such as to describe their house-type (single-storey house, two-storey or multi-storey building), to name the rooms in their house, to describe their own room, or what objects are in different rooms. The result of such an activity can be seen in Figure 1, where pupils were encouraged to describe their house-type. After the pupils' descriptions, the pre-service teachers added the name of this pupil to the group living in this kind of house type.

Pupils were furthermore encouraged to describe or express themselves by drawing or painting. This form of expression is quite familiar to the pupils, as mentioned by many preservice teachers in their reports, and therefore the pupils used this type of expression easily. Figure 2 shows drawings of their homes. Drawing $2 \mathrm{a}$ represents a single-storey building, while Figure $2 \mathrm{~b}$ and $2 \mathrm{c}$ multistory buildings. It is interesting that in the last picture the pupil depicted also the people who live there.

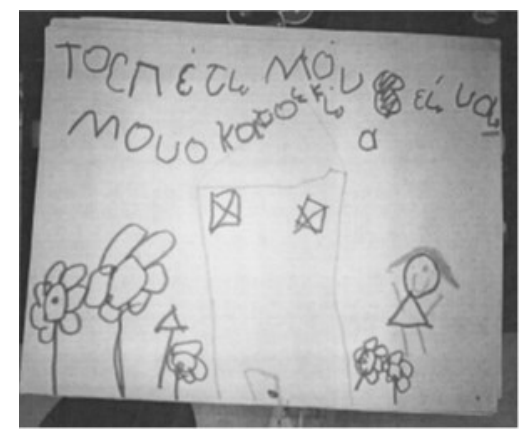

a

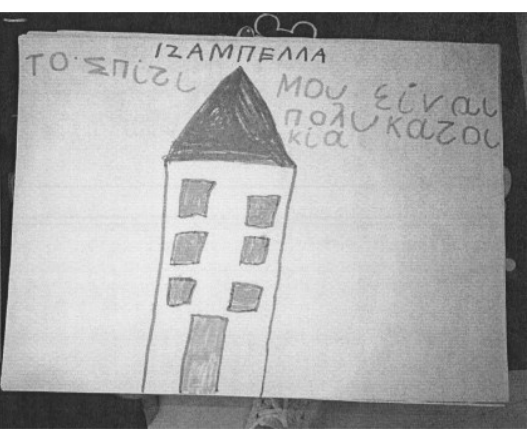

b

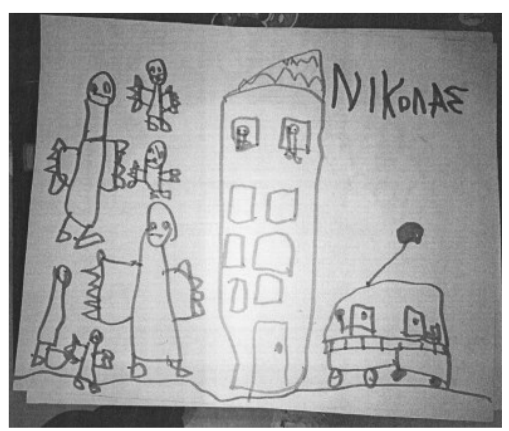

c

Figure 2. Drawings of the Pupils' Homes: (a) Represents a Single-Storey House, While (b) and (c) Multistorey Houses 


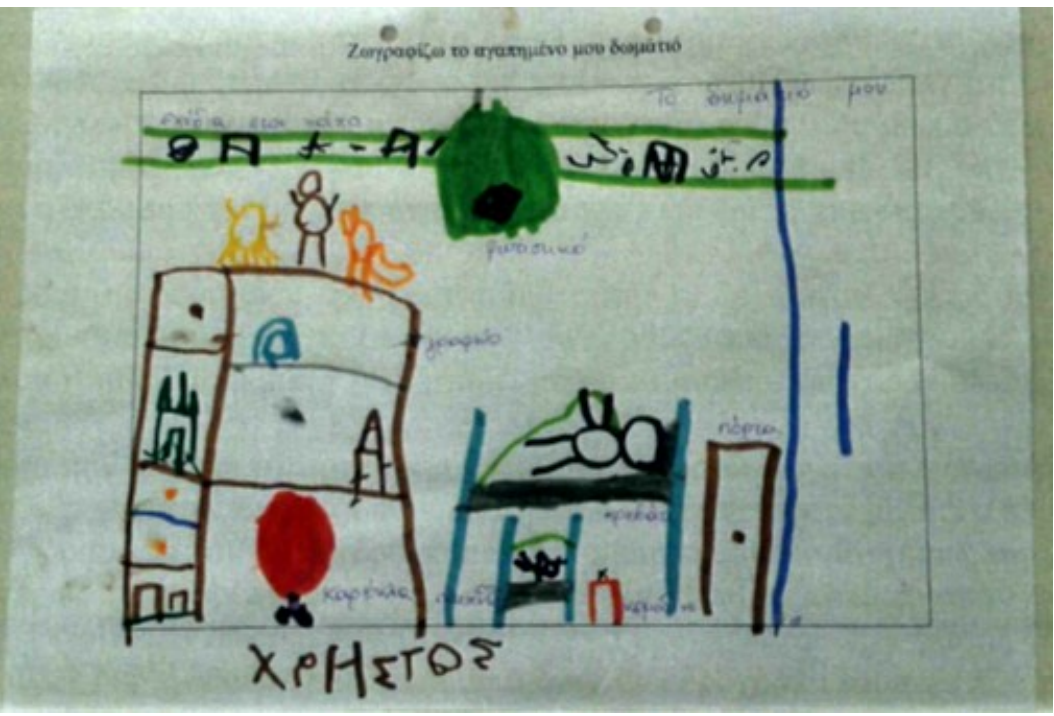

Figure 3. Picture of a Pupil's Favorite Room with a Description of the Furniture by the Pre-Service Teachers

Figure 3 depicts a description of a pupil's room. In this picture, the pre-service teachers added written descriptions of the words the pupil used to describe his room. We can see his bed, bed-side table, desk, chair, toys, his paintings on the wall, the light, and the door to his room.

The pupils created furthermore constructions or models. They built small houses using recycled materials, like milk or juice cartons, or toilet-paper-rolls, which were covered with paintings and finally glued on cardboards to represent a village, or a green city (Figures 6 and 13). They were invited to observe things, as for example pictures of houses from different places around the world. Pupils were encouraged to represent situations or activities using their bodies in role-play, pantomime, or theatrical representations, etc. Gluing and cutting activities did also occur quite often.

During the description of the activities, the preservice teachers mention the materials they used for the activities or suggested to the pupils to use ( 89 times mentioned). The mostly used materials are (and times mentioned in brackets) are: cardboard (38), markers (33), paper (33), cartons/boxes (25), pictures (18), glue (16), scissors (12), worksheets (8), wood pieces (6), reading fairytales (5), using the internet (5), plasticine (5), pencils (5), computer (5), maps (4), books (3), straws (3), chalks (3), torch (3).

\subsection{Dimensions of ESD}

All groups approached ESD through the societal dimension. Fewer pre-service teachers tackled the environmental dimension of houses. As for the financial dimension, only two short mentions appeared in two reports.

\subsubsection{Analysis of the Societal Dimension of ESD}

Some of the approaches used to start examining houses were:

- Asking the pupils to describe their house as a single-storey, two-storey or multistory building

- Drawing or painting houses (either the pupils' houses, or a relative's house or their dream house or a house from a story, e.g. the three little pigs and the wolf)

- Asking the pupils to describe using words or role-play or drawings what they do in their houses

- Examining houses of other cultures

- Examining traditional houses and the evolution of houses throughout history

- Constructing houses with the pupils to build a community, sometimes the pupils were asked to draw also the streets, parks, etc.

Table 1 shows the activities the pre-service teachers applied during their practicum to introduce the pupils to the subject houses and their societal dimension. 
Table 1. Activities on Societal Dimension of Houses and Their Frequency

\begin{tabular}{ll}
\hline Societal dimension of houses & Count \\
\hline Rooms of the house & 38 \\
Houses from around the world & 34 \\
House types & 32 \\
Activities done in houses & 20 \\
Usefulness of houses & 19 \\
Houses throughout history & 16 \\
Cultural aspects of houses & 15 \\
Parts of which a house consists (doors, walls, etc.) & 12 \\
Houses in arts & 9 \\
Who takes part in building a house (occupations) & 8 \\
Objects in houses (furniture, lights, etc.) & 7 \\
Houses in different cultures & 6 \\
How houses are built & 4 \\
\hline
\end{tabular}

Activities about the rooms of a house, as naming the rooms, or objects that are in specific rooms, or what pupils do in rooms, occurred very often in the activities. The rooms with the highest mentions in discussions in descending order were the bathroom, the living-room, bedrooms, the kitchen, the storage-room, the balcony, garden and garage, and the children's room. Activities on houses from around the world are also a favorite theme. There were activities with the help of a map, where the different houses were attached to the places of their origin. Other similar activities were painting and describing such houses (Figure 4). In an analogous activity, presented in Figure 5, the pre-service teachers focused also on the people living in these houses, belonging to different cultures from around the world. In such cases, the pre-service teachers explained also about the different ways of living, dressing, and about the conditions (cultural and climatic) of the places they live, connecting thus the houses (forms and functions) with cultures and places. In Figure 5 the pupils had to paint and cut off the drawings of people from a worksheet and glue them next to the houses corresponding to their culture.

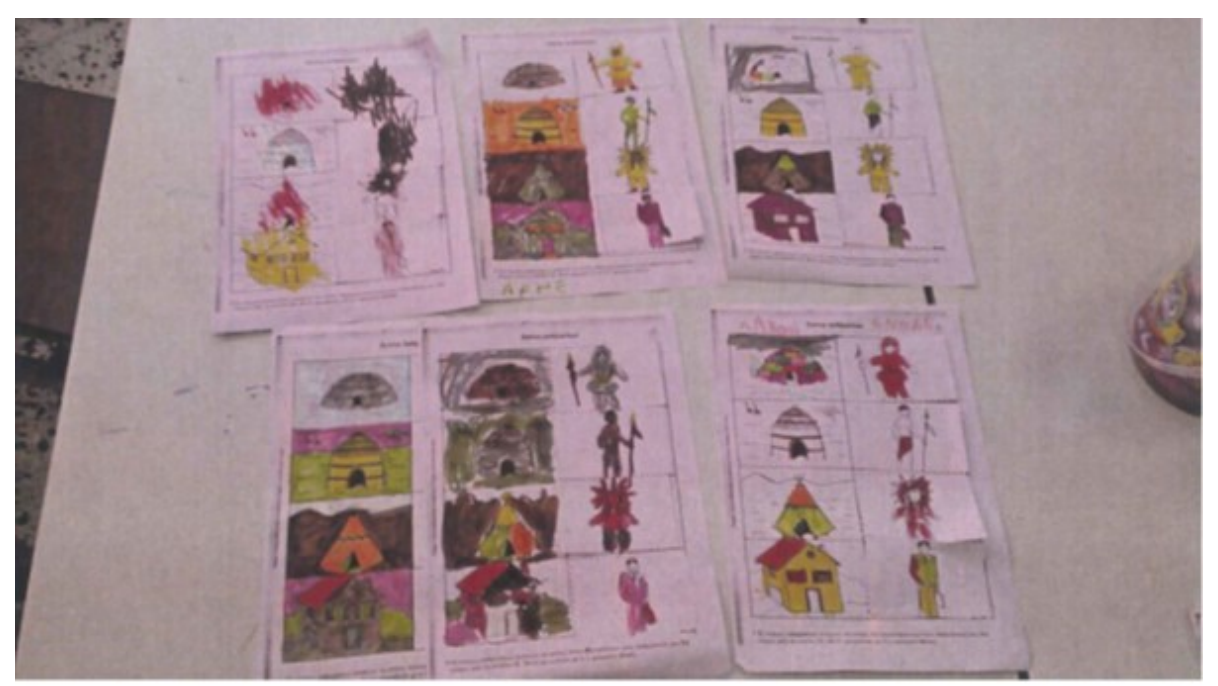

Figure 4. Pupils Drawing Houses from Around the World 


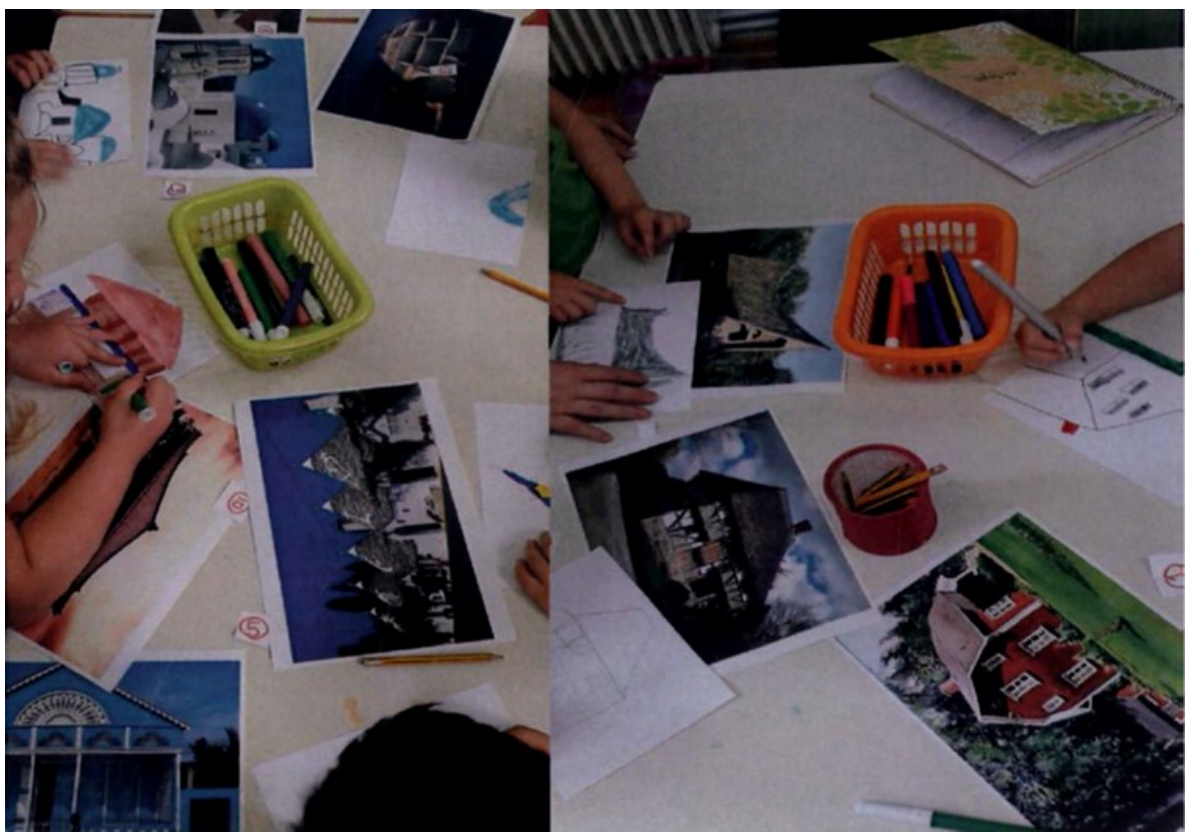

Figure 5. Houses and Their Inhabitants from Different Places Around the World

After describing their homes as single-storey, two-storey or multistorey houses, pupils were often asked to talk about activities the pupils or family members do at home. Here the pre-service teachers used drawings, discussions, and pantomime games, e.g. a game where one pupil performs an action and the rest of the pupils must guess what action he/she is doing, as wash my hands, sleep, etc. The preservice teachers also discussed frequently why we have houses, allowing the pupils to express themselves and understand the reasons houses are built. They furthermore discussed with the pupils that houses existed throughout history. In one case the pre-service teachers prepared pictures depicting the evolution of houses starting from caves, to settlements in lakes, to houses of wood and mud, stone, etc. Pupils were asked to describe the houses depicted and sort them in a correct timeline. The pre-service teachers described this activity as quite difficult for the pupils - they had often to give information on the houses and their evolution over time so that the pupils could perform the task.

Houses together form communities as depicted several times with the construction of villages (Figure 6), and the sustainabale city (Figure 13), letting the pupils draw communal buildings, as the school and church, and public spaces like playgrounds, parks, roads, etc.
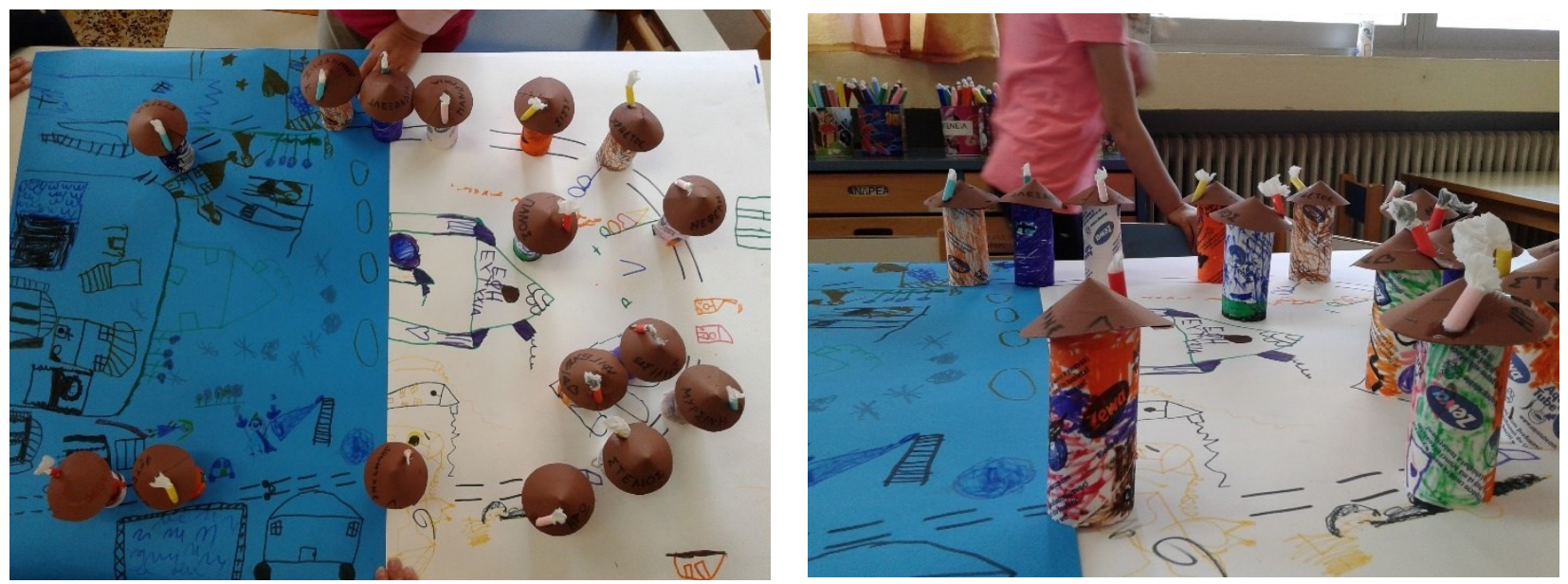

Figure 6. Houses of Constructed by the Pupils Glued Together to Form a Village 
Another activity where pupils had to describe a house was to name their parts, as for example doors, windows, walls, roof, ceiling, etc. Such activities were described by the pre-service teachers as very easy to complete by the pupils. The same outcome occurred also for things the pupils have in their houses, as different furniture items, clothes, toys, cutleries, musical instruments, etc.

The pre-service teachers used also houses in arts to initiate activities, as songs about houses, paintings, poems, and proverbs. All these means caught the pupils' interest and were considered as a starting point to many activities as drawing, dancing, singing, theatrical plays, etc.

Some pre-service teachers also created activities to discuss about the occupations involved in the construction of houses and the way houses are built, mentioning also building materials.

\subsubsection{Analysis of the Environmental Dimension of Houses}

Activities about the environmental dimension of houses the pre-service teachers decided to use, and their frequency are presented in Table 2 .

Table 2. Environmental Dimensions of Houses

\begin{tabular}{ll}
\hline Environmental dimension of houses & Count \\
\hline Orientation & 35 \\
Building materials & 34 \\
Apparent sun-path & 33 \\
Influence of climate & 20 \\
Sustainability & 13 \\
Bioclimatic architecture & 9 \\
Socrates' house & 5 \\
Surrounding of the houses & 4 \\
Solar water heater & 3 \\
\hline
\end{tabular}

Some groups analyzed the adaptation of houses to a specific location. The climate was the main factor used to do this, as for example igloos and African huts (an example is depicted in Figure 7).

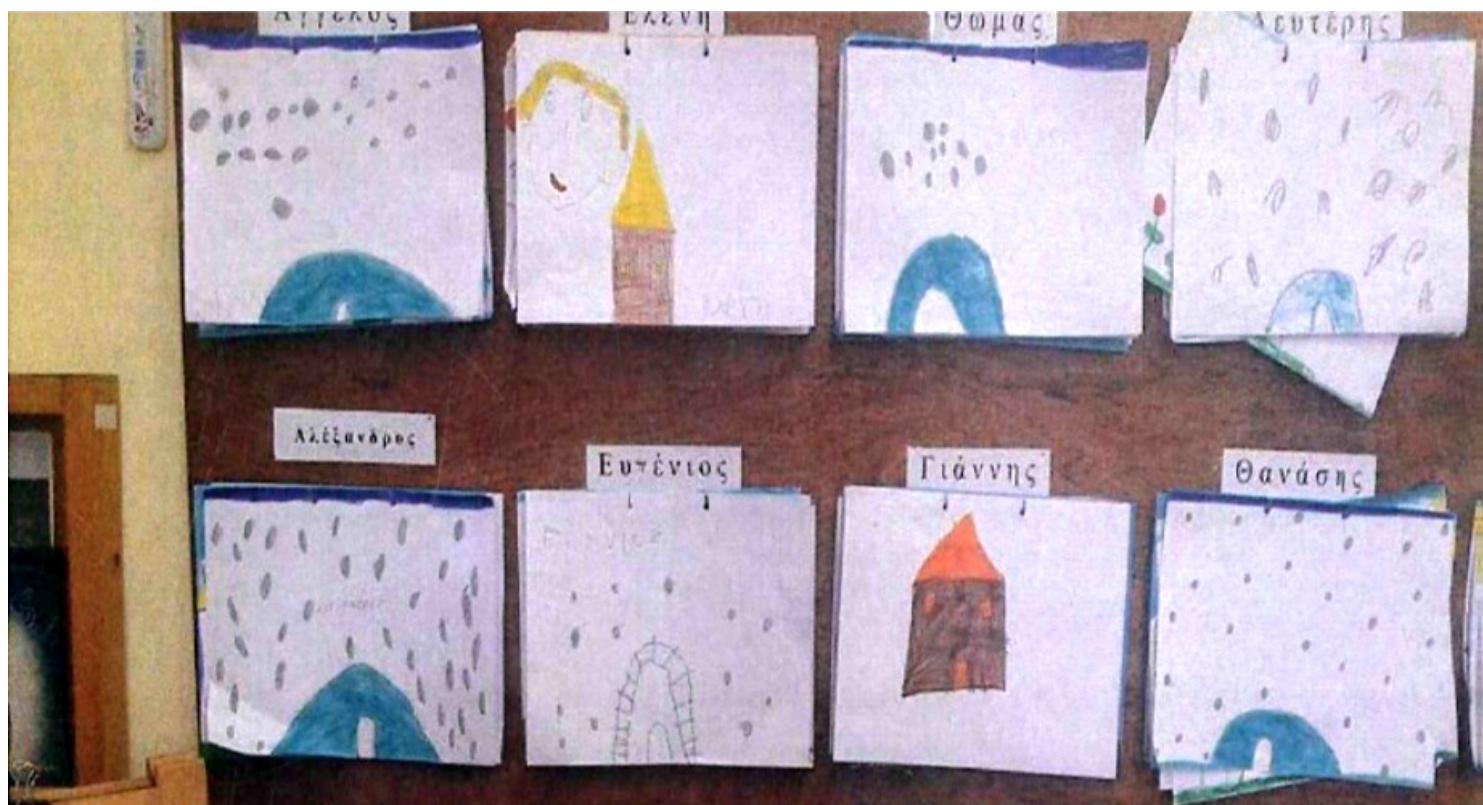

Figure 7. Houses Adapted to Extreme Weather Conditions (igloo - African hut) as Drawn by the Pupils

The same applied to traditional houses in Greece, focusing on the differences between island houses and houses in mountainous areas. The characteristic white houses with the flat roof or the houses of mountainous areas with their 
sloped roof exemplify such adaptations.

A pair of preservice teachers introduced the Earth's motion around the Sun, with one pupil playing the role of the Sun with a light torch in his/her hand and the Earth turning around the Sun and around itself causing day and night (day when facing the sun and night when he/she turned away. They followed this activity with painting a house during day and night (Figure 8)

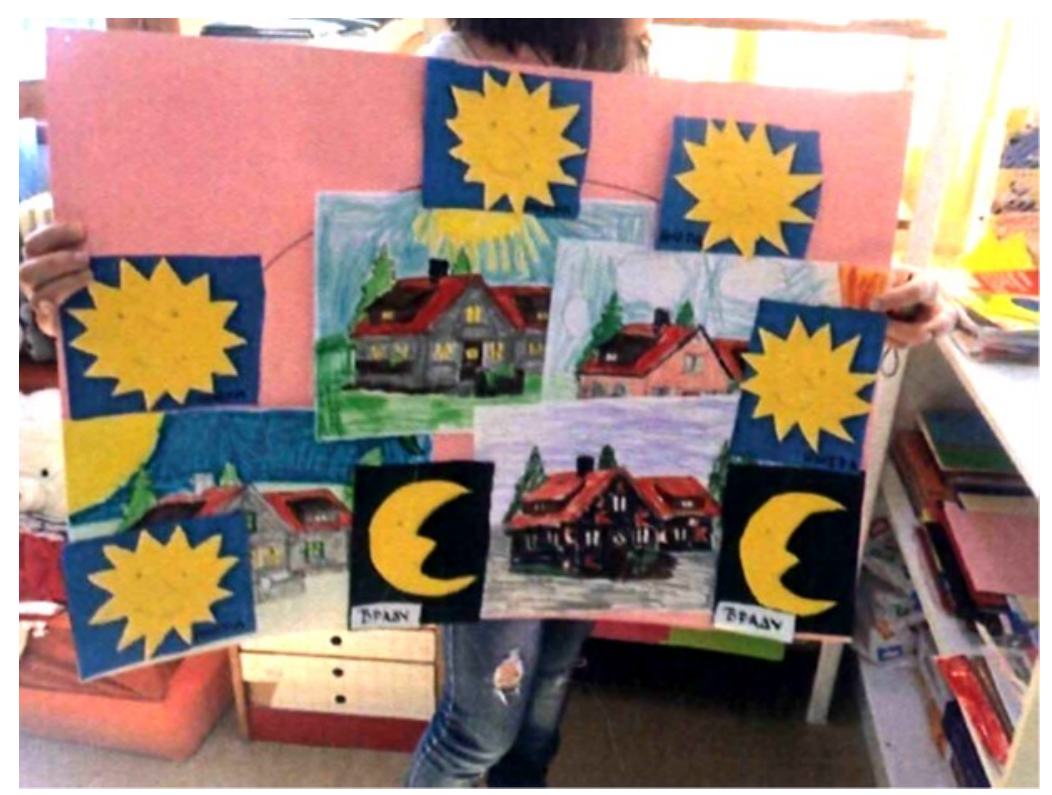

Figure 8. Houses during Day and Night

Some groups investigated the orientation of houses and had thus to introduce the cardinal points and observe the apparent sun-path with the pupils. In one of such activities, Figure 9, the pupils were asked to work in pairs, one standing and the other to draw the first pupil's shoes' outline to fix the position and the outline of the shadow he/she cast. The outline of the shadow was drawn after 1 and 2 hours. The pupils were surprised, and the standing ones tried to adjust their body to fit into the shadow. The preservice teachers had to explain about the apparent sun-path and ask the pupils to stand upright for the new position of the shadow to be drawn. A similar activity was performed by another pair of preservice teachers using a dollhouse, as presented in Figure 10. Again, the pupils were asked to draw the shadow of the dollhouse and redraw it every hour.

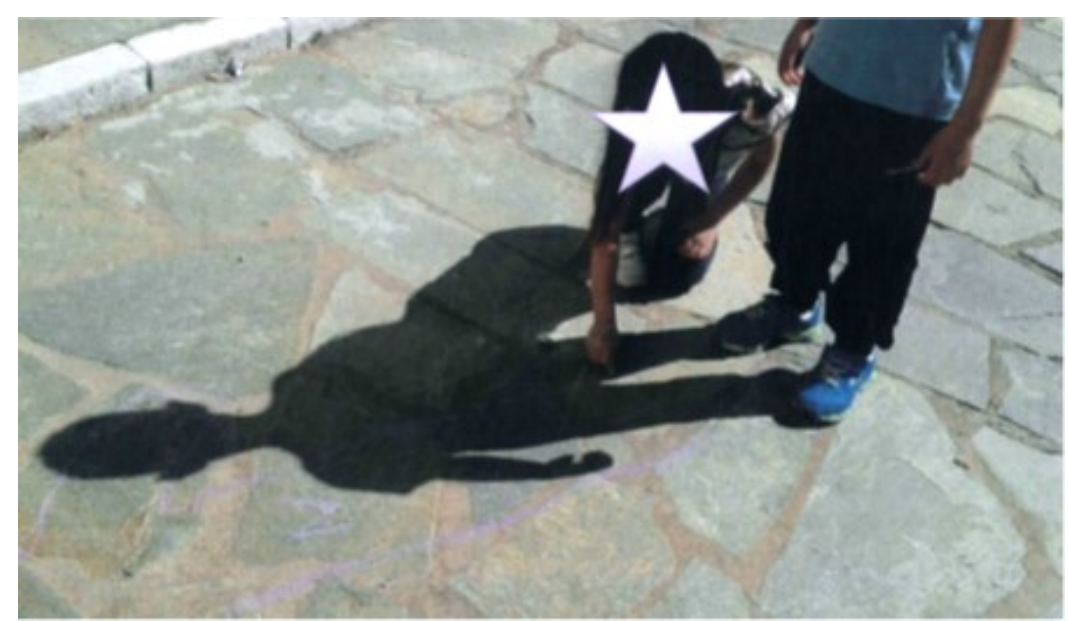

Figure 9. Observation of the Apparent Sun-Path with the Help of a Pupil and a Colored Chalk 


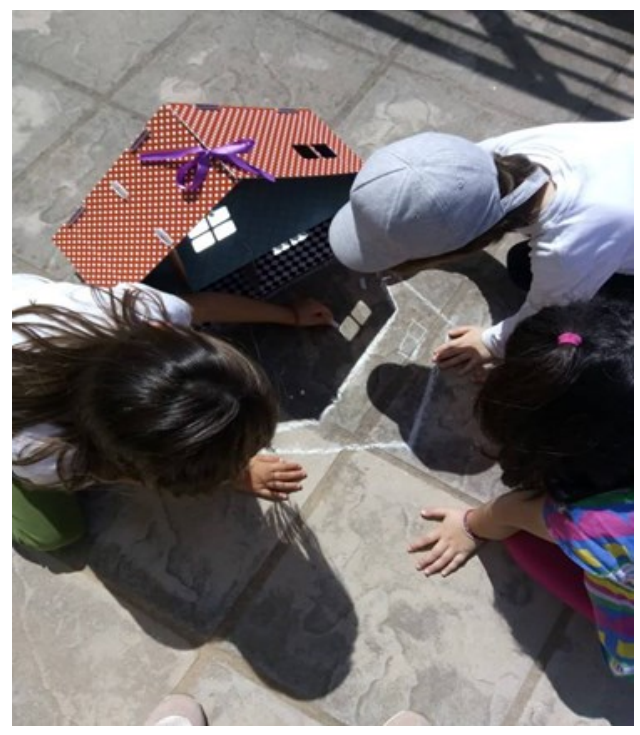

Figure 10. Pupils Documenting the Cast Shadow Due to the Apparent Sun-Path

These activities were followed by an indoor representation of the sun-path, with the pre-service teachers explaining the difference of the sun-path during summer and winter, namely that the sun rises only twice exactly East and sets exactly West, which occurs during the spring and autumn equinox, while during summer the sun rises Northeast and sets Northwest reaching its highest point during noon in comparison with winter, where the sun rises Southeast reaches a much lower apogee in comparison to the summer solstice and sets Southwest (Figure 11). This process was reconstructed by each pupil in the activity depicted in Figure 12.

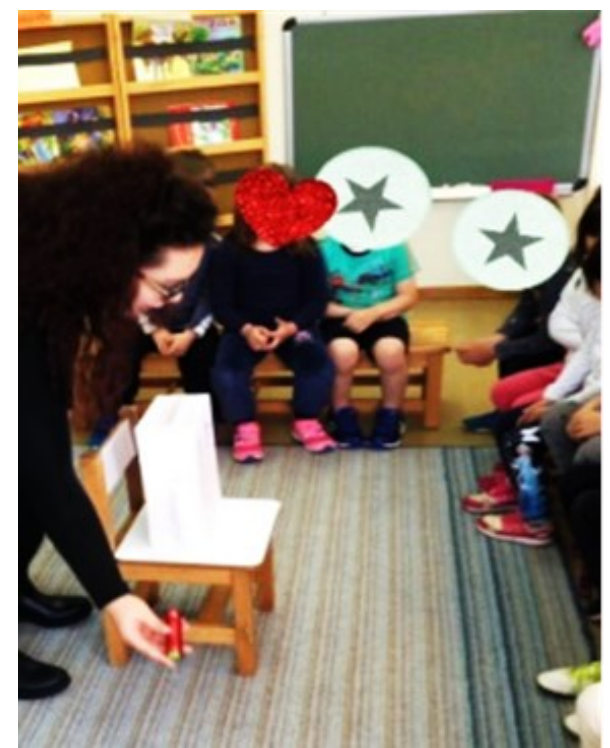

Figure 11. Presentation of the Apparent Sun-Path during Summer and Winter 


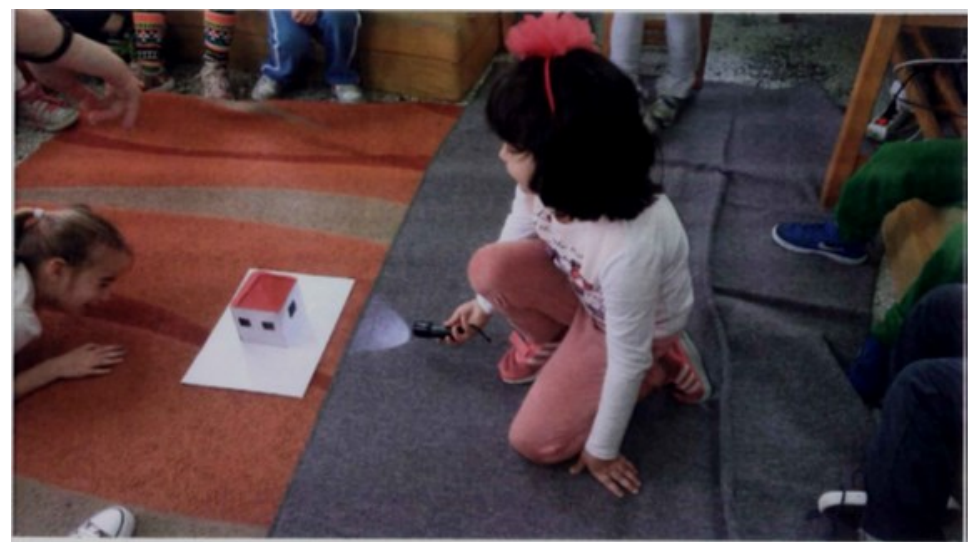

Figure 12. A pupil is Presenting the Apparent Sun-Path with the Help of a Torch (sun)

Some groups went even on to describe Socrates' house, namely how according to Socrates a house should be built, as presented in an excerpt from Xenophon's (1923) Memorabilia book $\Gamma^{\prime} 3.8 .8-3.8 .10$. In this way, these pre-service teachers introduced the principles of bioclimatic architecture, which is a way of designing a house in order to use the sun as the heating source and natural ventilation as a cooling mechanism. Following Socrates' description, they started by the importance of the right orientation of the main façade towards the South (for the Northern hemisphere), in order to have the sunrays from morning to evening entering the higher Southern windows to help heating the house during winter. During summer the apparent sun-path apogee is much higher and thus the sunrays can easily be blocked by a small projection of the roof of about 1 meter for Greece (Maidou, Plakitsi, \& Polatoglou, 2019b)

Renewable energy was also discussed by one group after a walk in the neighborhood, during which they observed houses with solar water heaters. After returning to the school, they explained the function of the solar water heater to the pupils and helped them to construct models of solar water heaters with simple everyday materials.

Another group introduced the young pupils to the notion of a sustainable city. They showed using a PC windturbines, solar water heaters, and solar panels and explained in a simple way about renewable energy sources. During the last day of their placement, they built with the pupils the city depicted in Figure 13. They discussed in detail about how a city should use its own resources of produce, grown nearby, and that all citizens must contribute to keep the city clean (air, water, soil), and use renewable energy sources.

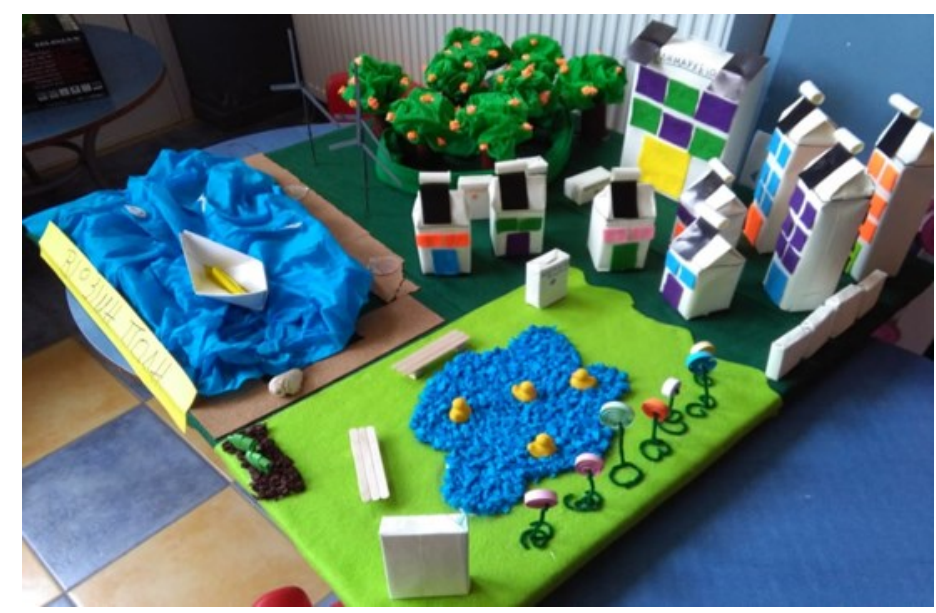

Figure 13. Sustainable City Which Uses Only Renewable Energy Sources

\subsubsection{The Financial Dimension of ESD}

The financial dimension was covered only twice and quite briefly, in the teaching scenarios containing renewable energy, as a cheaper energy source that is not harming the environment, and also, as a socioeconomic dimension, a 
castle was mentioned as a house for rich people.

\subsection{Pre-service Teachers Evaluation of Activities They Created and Applied}

The pre-service teachers designed and conducted 140 activities altogether during the week of their practicum. Of these, 22 activities were not relevant to the theme of houses, as for example activities on gardening, recycling, house-rules, etc. One was a misconception, where the pre-service teachers taught about building materials in a wrong way. Below we will present some teaching evaluations, as presented from their reports, and discuss the outcomes.

The pre-service teachers described the activities they designed, the aim of the activities, and evaluated their outcome. Most activities were described in a positive way with positive outcomes, sometimes as planned, sometimes better than expected, and sometimes with lesser than anticipated outcomes.

\subsubsection{Description of the Aim of the Activity}

The pre-service teachers described the aim of their activities. As such they mention:

During the design of their activities the pre-service teachers aimed for specific outcomes as presented in the following excerpt. They decided to use interactive teaching approaches, and design exercises to enhance the pupils' practical skills and skills in oral expression:

The aims of this activity are: a) to inquire about the notion house (rooms, what we do in houses, building materials) from the answers of the pupils themselves, and not by lecturing them, b) practicing fine motor skills (cutting with scissors and writing) and c) pupils must present their work to their peers (Maria, Dimitra).

The following excerpts present also the desired outcomes for the pupils - they should gain skills in oral expression and argumentation and practical skills to express themselves through sketches and drawings:

The aims [of these activities] are the pupils to participate in discussions and to use reasoning. [They have] to be able to describe houses, to explain, interpret and narrate. Also, pupils should experiment with different materials and colors [pensils, crayons, watercolor, etc.], to learn various techniques, and apply them to their sketches and drawings (Christina, Dimitris).

[the pupils should be able] to name the rooms of a house, and the various activities that take place in these rooms (Maria, Maria).

... communicating and collaborating with others, respecting others and the rules of the group, dealing with difficulties, developing relationships, understanding how the world around them works (specifically their home), choosing the right vocabulary, listening, constructing simple three-dimensional constructions using various materials to create something, make drawings (Christina, Andy).

The pre-service teachers introduce also the scientific method as described in the three following excerpts:

The main goals of this activity are [for the pupils] to understand basic characteristics of the properties of materials. They should also understand the importance of observation, experimentation, and description for the study of materials and phenomena. Finally, it is especially important for children to explore features of the natural and artificial world (Christina, Dimitris).

An important issue of this activity is for the pupils to reflect on and inquire about a variety of situations, to build on previous knowledge and experiences, to make simple hypotheses, and come to conclusions (Anna, Dora).

... this activity has some processes of the scientific method. In this specific, activity the pupils developed the abilities of observation, classification, experimentation, and construction of models (Maria, Dimitra).

One group was very precise about ESD and buildings. After introducing their pupils to renewable energy sources, like wind turbines, heating a house by the sun, using solar heaters for warm water and recycling waste materials, they designed a sustainable city, with clean air, a lot of green spaces, solar water heaters and solar panels, local production of food and clean water. They described the aim of their activity to be:

... communication and coworking among peers, respecting each other and the rules of the group, ... to identify the renewable energy resources, to recognize human activities as factors that can preserve the balance of nature, appreciate the contribution of attitudes and behaviors that protect the planet, adopt positive attitudes and behaviors towards the environment and its protection, to familiarize [pupils] with waste management strategies, ... use of various materials for the construction of different forms and items of three-dimensional structures (Figure 13). (Andy, Christine) 


\subsubsection{Positive Outcomes}

Pre-service teachers describe the outcomes of their activities in positive ways when the pupils understand and learn:

... the experience of ice and wood caused [the pupils] many questions and concerns about their use [as building materials for igloos and African huts]. When they saw that the ice cubes were melting, they wondered even more and became concerned. Initially, they did not know the reason why ice cubes were melting. During the process, however, they found out that when a frozen material warmed up, it would melt. And what can cause this [we asked]? The sun they responded. So, they understood that such homes can exist in low-temperature environments ... (Christina, Dimitris).

There were no cases of cognitive conflicts except for the igloos when [the pupils] were told that the interior is warm, and the ice is essentially insulating and does not let the cold enter. The pupils had the impression that it would be cold because of the ice ... initially, this seemed to trouble them and some [pupils] expressed this view (Maria, Maria).

The pre-service teachers seem worried to fail catching the pupils interest and engage them in the activities they designed:

We started this activity with a few pupils, because most of them wanted to engage in other activities, but then they collaborated and completed the activity. They succeeded in completing and designing what they were asked to do carefully and successfully (Eva, Eugenia).

The pre-service teachers describe proudly their achievements to motivate and engage the pupils, especially when they participate enthusiastically:

The pupils participated enthusiastically in the discussion, because they were asked to describe something very familiar to them, their home. Each gave a different detail about his or her home, especially when we asked them to describe their room. They illustrated all the images they had of the various house-types they knew and showed great curiosity when we showed them "strange" houses from other parts of the earth they saw for the first time. We encountered no particular difficulty beyond the fact that everyone wanted to talk about their home first and describe it to us! (Maria, Dimitra).

The pre-service teachers dared to introduce new ways of teaching, as can be seen from the following two excerpts. In the first one, they introduced pantomime as a way of communication, while in the second one another group described how they used Google Maps to navigate virtually from each pupil's home to school.

The pupils had not played pantomime again, so they felt strange that they had to express something with their body rather than speaking. They liked the process very much and the game went on longer than we had planned. They wanted all to take part and created fuss about who would start first (Maria, Maria).

The pupils experienced with the help of the internet [and Google Maps] their everyday environment in a different way. They felt great joy when they showed us their home, yard or balcony and neighboring houses [through the street view]! They described who is living next to them, whom they are playing with, where their room is, how they walk to school, ... Their descriptions were incredibly detailed, and we were impressed by the variety of linguistic elements they used. Concepts such as small-large, high-low, inside-out, detached-apartment-house, with garden or balcony, elevator or staircases were mentioned ... The pupils seemed quite familiar with the technology, some even managed the computer mouse with great skill and their comments were very intelligent (Anna, Marina).

Furthermore, the pre-service teachers praised the results they got and the ability of the pupils to express themselves creatively:

... While during the previous week we were observing a uniformity in paintings and the children were looking at each other's paintings to get ideas, now we were delighted to see a variety of different shapes (triangles and round windows and not just squares, two-storey houses, single-storey houses, a variety of colors, flowers and a lot of green color around the houses and in all the paintings the existence of a bright sun with huge rays!) (Sofia, Maria).

The pre-service teachers praised also the pupils' willingness for collaboration and mutual support during the construction of a village in which all pupils contributed with houses:

We did not expect such a good response from the class. They were excited and joyful by their creation. Everyone wanted to help us and their classmates. Their paintings were very elaborate, full of flowers, pots, etc. 
When the models of the houses, as well as the school-building were finished, the children glued everything on the cardboard and wanted eagerly to explore it. So, they were sitting on the carpet and observing which house was not well glued or needed some repair. They were also commenting on which child created each house ... and finally rewarded each other for the good work they did (Angeliki, Vasiliki).

\subsubsection{Negative Outcomes}

To design activities without knowing the class bared the risk of designing too difficult activities, as described in the following passage:

The activity was very difficult for the children. When we tried to come up with questions that would bring them to reasonable conclusions or situations that they knew but were escaping them at that moment, most children engaged, though they seemed to get bored (Nicol, Dina).

The pre-service teachers faced discipline problems, as described in the following excerpt, where all pupils wanted to talk simultaneously, or in the second excerpt, with two pupils exhibiting disturbing attitudes to their peers and thus hindering the teaching and learning process:

And the conversation between them erupted again. The schoolteacher had to intervene to calm them down, as they all talked together at the same time. The next few days I drafted a game with a ball that I brought from my home to get some order, telling them that the one who gets the ball may talk. And so, everyone was waiting for their turn to get the ball and talk (again there were times when my plan wasn't $100 \%$ successful) (Maria, Maria).

The only difficulty we encountered was with two children who had not only difficulties taking part in our activities but also the tasks and lessons of the schoolteacher. The schoolteacher explained, that the girl was in the early stages of autism, and that she is unable to develop emotional relationships with other people, her attention gets easily distracted, and she cannot focus. ... The boy comes from a family that doesn't care about him. His parents have neglected him and are not interested in his social behavior; therefore, the child reacts negatively to many things, beating and disrespecting other children. During the activities the boy would come and grab the activity materials, destroying the feeling of cooperation and distracting the other pupils. The schoolteacher intervened when there was too much tension and took the children for a walk to improve their behavior without shouting and punishments (Dimitra, Anna).

Another difficulty the preservice teachers faced was with the pupils who did not want to participate in an activity:

A girl got tired by the construction of the compass and didn't want to continue with the worksheet. We didn't push her, [and] in the end she decided to get involved [in the activity].... (Anna, Maria).

\subsection{Pre-service Teachers Feedback from the Practicum}

The feedback on the practicum although generally described as a positive experience was also challenging for some groups:

The children liked the activity - they liked it and wanted to do other similar activities. However, from our side, we were not particularly pleased, and the reason was the involvement of the schoolteacher who had not informed us that she wanted to take part in the activity. The schoolteacher decided without our consent to present our activities to the children. She explained why and how the human body functions as a compass This fact left us a little speechless because we were invited to watch our activity [presented and conducted by her] (Katerina, Irma).

Not all pre-service teachers made final remarks on their experience, but most of them did seem pleased to have faced problems in an actual teaching environment:

This experience was unprecedented for us. In practice, we realized that the function of the early childhood teacher is based on both pre-planned activities and the teacher's improvisation and readiness. We have developed very good relationships with the schoolteachers and pupils, and we are pleased with our results (Andy, Maria).

Through this practicum, we have learned to observe and deal with pre-school children and their particularities. We also gained a lot of experience, knowledge, and had fun with the pupils (Maria, Maria). 


\section{Discussion}

The preservice teachers recognized the importance of ESD and introduced it in their teachings, providing more opportunities for students to become active citizens that care to adopt sustainable living styles (Bell, 2016; Hägglund \& Pramling Samuelsson, 2009; Haigh, 2008).

All groups of preservice teachers used interactive teaching approaches during their practicum, as suggested by many scholars to be the most effective way to teach about SD (Biasutti, 2015; Christie et al., 2013; Corney \& Reid, 2007; Lysgaard \& Simovska, 2016; McNaughton 2012; Saka \& Sahintürk, 2013; Tomas, Girgenti, \& Jackson, 2017; UNESCO, 1992), encouraging the young pupils to express themselves by many means as speaking, drawing, playing, pantomime, etc. When the pupils had difficulties to find solutions, the preservice teachers tried to assist them through questions, or through experience, trying to stay supportive in the background to the pupils learning experiences.

The community members that supported the preservice teachers were the cooperating pre-schools and schoolteachers on one hand and the university teachers of the Early Childhood Department on the other hand. A contradiction in the community was experienced by the pair of preservice teachers who described that the schoolteacher decided to use the materials they had designed and prepared to teach the pupils and hand out the photocopies the preservice teachers had prepared. In this way, she used her power to hinder the preservice teachers from completing their activity. The secondary contradictions occurred sometimes among the tools and the object of the activity. The design of the activity seemed to be too difficult for the young pupils in some occasions.

Our study confirmed that placing preservice teachers in pairs in the school practicum can support learning through the promotion of collaboration and dialogue, supporting more expansive and deeper learning (Brown \& Roth, 2002; Sorensen, 2014). Similarly, to the results of Engeström (1987) and Brown and Roth (2002), we observed that the placement in pairs empowered the preservice teachers by enabling them to share their uncertainties and in this way, reaching a better outcome of a more advanced, collectively achieved activity. One pair experienced though contradiction in their collaboration, as also experienced in a case described by Brown and Roth (2002). Namely, one student complained that their groupmate was not cooperating and contributing to the design of the activities, she even neglected her university responsibilities according to the description of the other party. Therefore, the student decided to do all the work on her own. This resulted in anxiety because she had to make all the decisions on her own and furthermore conduct all activities without help.

The preservice teachers were free to design their curriculum of the sustainability issues they would apply during their internship. This led to developing of teachers' agency, which is consistent with previous findings of other studies (El Kadri \& Roth, 2015; Eraut, 2014; Gan \& Lee, 2016), finding that the ability to design their activities is transformative for new teachers, acquiring an agential identity through the process (El Kadri \& Roth, 2015; Fuller \& Unwin, 2004).

Furthermore, the issue houses we chose to utilize during our TIs proved to be a suitable paradigm, since it contributed to the preservice teachers' engagement during the TIs, because it relates to their everyday life. Additionally, it appeared also to be appropriate for young pupils, as a familiar subject to them, enabling the pre-service teachers to build on the pupils' former knowledge.

During the short-time placement of the pre-service teachers, they had to face difficulties, tensions, and contradictions. The subject of ESD is complex and multifaceted. What they had learned during the TIs had to be selectively adapted to the level of pre-school pupils. They had to prepare teaching activities and materials for a class they did not know, which even for experienced teachers poses tensions about how far and deep a subject can be taught. They had no former teaching experience, so they had to base their teaching scenarios on the theoretical knowledge from their university studies.

In general, we could say that all participating preservice teachers started an expansive learning cycle (Engeström, 1987) during the design and conduction of the activities. The expansive cycles started with Questioning, and more precisely with the question of what to teach about SD and how to teach about it to pre-school pupils during the short time of their placement. This process was continued by the Analysis state, which occurred among the students during the preparation of their internship activities and among the students and the researchers. The students, in pairs, had to answer the question of what and how to teach about ESD to young pupils, how to apply the issue houses with the young ones, and what activities would be appropriate to motivate them to engage in the learning process. During the 3rd and 4th action of the expansive learning cycle, they modeled their approach in pairs and examined the model. The 5th action was the implementation of the model during the internship, followed by the written report, where they reflected on the process, describing what went well or not so well, and possible reasons why some activities might 
not have the outcome they wished for. The expansive learning cycle of the pre-service teachers lacked the final action of consolidation of the new practice.

During the process of the expansive learning cycle, the preservice teachers faced tensions, contradictions, dilemmas, and disturbances. They encountered primary contradictions of themselves as the subjects of the activity since they had no former teaching experience, they furthermore were not confident on how to teach about such a complicated and multifaceted subject as SD, and additionally, they did not know the class they were assigned to, since the activities they had to design had to be appropriate for that specific class, or they had to be able to adapt the content to the actual class. Primary contradictions were also experienced about the tools, namely the activities they designed and teaching approaches they intended to use, and if these were appropriate to attract the interest of young pupils and to maintain it. The rules of the community had been set by the schoolteacher, therefore in their interaction with the pupils, they should follow mainly those rules. Contradiction in the rules was also experienced by the pre-service teachers' group with the pupils who wanted to talk all at once and made a fuss, as well as the group who had the two pupils with the disturbing behavior towards their peers (section 3.3.3). The learning community, as was the schoolteacher and the pupils were not known to the pre-service teachers, and it was uncertain how much independence the schoolteacher would give them in managing the class, and likewise, they did not have control over the division of labor between the pre-service teacher and the schoolteacher. Another contradiction in the division of labor was sometimes the unwillingness of the pupils to take part in the activities, as the pupils who showed boredom or the girl who was unwilling to take part in an activity at the beginning but did eventually take part. There were additional doubts and dilemmas about the object of the pre-service teacher's practicum and whether this would lead to the desired outcome, which were both to gain positive experiences from their placement in the pre-school for the pre-service teachers, and to teach pupils about sustainability. As inexperienced teachers, they faced additional secondary contradictions and tensions as to whether the teaching scenarios and the material they had designed and prepared would be appropriate for the object of the activity.

From the overall outcome of the pre-service teachers' practicum, it is obvious that the pre-service teachers completed the actions of the expansive cycle except for the final action, that of consolidation of the new practice. This stage is furthermore more or less never reached even by experienced teachers since new knowledge or teaching practices change over time. This applies especially to ESD since it is not a set of knowledge that can be acquired (Wiek, Withycombe, Redman \& Banas Mills, 2011) but a complex notion still evolving (McKeown, 2002). To address emerging sustainability issues, teachers need life-long training by higher education institutions and therefore the expansive learning cycle for pre-service and in-service teachers will have to go on, adapting to the evolving problems humankind is facing.

\section{References}

Allen, J. M. (2009). Valuing practice over theory: How beginning teachers re-orient their practice in the transition from the university to the workplace. Teaching and Teacher Education, 25(4), 647-654. https://doi.org/10.1016/j.tate.2008.11.011

Anderson, A. (2013). Climate Change Education for Mitigation and Adaptation. Journal of Education for Sustainable Development, 6(2), 191-206. https://doi.org/10.1177/0973408212475199.

Bekessy, S., Burgman, M., Wright, T., Leal Filho, W., \& Smith, M. (2003). Universities and sustainability. Tela: Environment, Economy and Society, 11. Retrieved from http://www.acfonline.org.au/docs/general/00470.pdf.

Bell, D. V. J. (2016). Twenty-first Century Education: Transformative Education for Sustainability and Responsible Citizenship. Journal of Teacher Education for Sustainability, 18(1), 48-56. https://doi.org/10.1515/jtes-2016-0004.

Biasutti, M. (2015). An intensive programme on education for sustainable development: the participants' experience. Environmental Education Research, 21(5), 734-752. https://doi.org/10.1080/13504622.2014.921805.

Braun, V., \& Clarke, V. (2006). Using thematic analysis in psychology. Qualitative Research in Psychology, 3(2), 77-101. https://doi.org/10.1191/1478088706qp063oa.

Brown, G. M., \& Roth, W. M. (2002). Student teachers' perceptions of their paired practicum placement experiences. Journal of Teaching and Learning, 2(1), 21-37. https://doi.org/10.22329/jtl.v2i1.140

Burmeister, M., \& Eilks, I. (2012). An example of learning about plastics and their evaluation as a contribution to Education for Sustainable Development in secondary school chemistry teaching. Chemistry Education Research 
and Practice, 13(2), 93-102. https://doi.org/10.1039/C1RP90067F

Campbell-Evans, G., \& Maloney, C. (1997). An alternative practicum curriculum: Exploring roles and relationships. Asia-Pacific Journal of Teacher Education, 25(1), 35-52. https://doi.org/10.1080/1359866970250104

Christie, B. A., Miller, K. K., Cooke, R., \& White, J. G. (2013). Environmental sustainability in higher education: how do academics teach? Environmental Education Research, 19(3), 385-414. https://doi.org/10.1080/13504622.2012.698598

Cohen, E., Hoz, R., \& Kaplan, H. (2013). The practicum in preservice teacher education: a review of empirical studies. Teaching Education, 24(4), 345-380. https://doi.org/10.1080/10476210.2012.711815

Corney, G., \& Reid, A. (2007). Student Teachers' Learning about Subject Matter and Pedagogy in Education for Sustainable Development. Environmental Education Research, 13(1), 33-54. https://doi.org/10.1080/13504620601122632

Cortese, A., \& Hattan, A.S. (2010). Education for sustainability as the mission of higher education. Sustainability, 3(1), 48-52. https://doi.org/10.1089/SUS.2009.9802

Cotton, D. R. E., \& Winter, J. (2010). It's not just Bits of Paper and Light Bulbs: A review of Sustainability Pedagogies and their Potential for use in Higher Education. In Jones, P., Selby, D. and Sterling, S. (Eds.), Sustainability Education: Perspectives and Practice Across Higher Education. London, UK: Earthscan. https://doi.org/10.1080/13504620701659061

Danielewicz, J. (2001). Teaching selves: Identity, pedagogy, and teacher education. Albany, NY: State University of New York Press.

Darling-Hammond, L. (2006). Constructing 21st-century teacher education. Journal of Teacher Education, 57(3), 300-314. https://doi.org/10.1177/0022487105285962

Darling-Hammond, L. (2012). Powerful teacher education: Lessons from exemplary programs. San Francisco: Jossey-Bass.

Deed, C., Cox, P., \& Prain, V. (2011). Enablers and constraints in achieving integration in a teacher preparation program. Australian Journal of Teacher Education, 36(8), 68-86. https://doi.org/10.14221/ajte.2011v36n8.3

Dobbins, R. (1996). Student teacher self-esteem in the practicum. Australian Journal of Teacher Education, 21(2), 16-28. https://doi.org/10.14221/ajte.1996v21n2.2

El Kadri, M. S., \& Roth, W.-M. (2015). The teaching practicum as a locus of multi-leveled, school-based transformation. Teaching Education, 26(1), 17-37. https://doi.org/10.1080/10476210.2014.997700

Engeström, Y. (1987). Learning by expanding. An activity-theoretical approach to developmental research. Helsinki, Finland: Orienta-Konsultit Oy.

Engeström, Y. (2000). Activity theory as a framework for analyzing and redesigning work. Ergonomics, 43(7), 960-974. https://doi.org/10.1080/001401300409143

Engeström, Y. (2001). Expansive learning at work: Towards activity theory reconceptualisation. Journal of Education and Work, 14(1), 133-156. https://doi.org/10.1080/13639080020028747

Engeström, Y. (2008). Weaving the texture of school change. Journal of Educational Change, 9, 379-383. https://doi.org/10.1007/s10833-008-9086-6

Engeström, Y. (2016). Foreword Making Use of Activity Theory in Educational Research. In D. S. P. Gedera and P. J. Williams (Eds.), Activity Theory in Education. Research and Practice. (pp. vii-ix). Rotterdam, The Netherlands: Sense Publishers.

Engeström, Y., Rantavuori, J., \& Kerosuo, H. (2013). Expansive Learning in a Library: Actions, Cycles and Deviations from Instructional Intentions. Vocations and Learning, 6(1), 81-106. https://doi.org/10.1007/s12186-012-9089-6

Engeström, Y., \& Sannino, A. (2010). Studies of expansive learning: Foundations, findings and future challenges. Educational Research Review, 5(1), 1-24. https://doi.org/10.1016/j.edurev.2009.12.002

Eraut, M. (2014). Developing Knowledge for Qualified Professionals. In O. McNamara, J. Murray, \& M. Jones (Eds.), Workplace Learning in Teacher Education: International Practice and Policy. (pp 47-72). Dordrecht: Springer. https://doi.org/10.1007/978-94-007-7826-9_3 
Ferrier-Kerr, J. L. (2009). Establishing professional relationships in practicum settings. Teaching and Teacher Education, 25(6), 790-797. https://doi.org/10.1016/j.tate.2009.01.001

Fuller, A., \& Unwin, L. (2004). Expansive learning environment integrating organizational and personal development. In H. Rainbird, A. Fuller \& A. Munroe (Eds.), Workplace learning in context (pp. 126-144). London: Routledge. https://doi.org/10.4324/9780203571644

Gan, Z., \& Lee, F. K. J. (2016). Understanding ESL Student Teachers' Learning of Classroom Practices in the Practicum: A Case Study in Hong Kong. Asia-Pacific Education Researcher, 25(2), 251-266. https://doi.org/10.1007/s40299-015-0258-x

Garrard, G. (2010). Problems and Prospects in Ecocritical Pedagogy. Environmental Education Research, 16(2), 233-245. https://doi.org/10.1080/13504621003624704

Gayford, C. G., \& Dillon, P. J. (1995). Policy and the practice of environmental education in England: a dilemma for teachers. Environmental Education Research, 1(2), 173-184. https://doi.org/10.1080/1350462950010204

Goodnough, K., Osmond, P., Dibbon, D., Glassman, M., \& Stevens, K. (2009). Exploring a triad model of student teaching: Pre-service teacher and cooperating teacher perceptions. Teaching and Teacher Education, 25(2), 285-296. https://doi.org/10.1016/j.tate.2008.10.003

Graham, B. (2006). Conditions for successful field experiences: Perceptions of cooperating teachers. Teaching and Teacher Education, 22(8), 1118-1129. https://doi.org/10.1016/j.tate.2006.07.007

Griffiths, T., \& Guile, D. (2004). Learning through work experience for the knowledge economy: Issues for educational research and policy. Luxembourg: Office for Official Publications of the European Communities. Retrieved from https://www.cedefop.europa.eu/files/3034_en.pdf.

Hägglund, S., \& Pramling Samuelsson, I. (2009). Early childhood education and learning for sustainable development and citizenship. International Journal of Early Childhood, 41(2), 49-63. https://doi.org/10.1007/BF03168878

Haigh, M. (2008). Internationalisation, planetary citizenship and Higher Education. Compare, 38(4), 427-440. https://doi.org/10.1080/03057920701582731

Haigh, M., \& Ward, G. (2004). Problematising practicum relationships: Questioning the 'taken for granted'. Australian Journal of Education, 48(2), 134-148. https://doi.org/10.1177/000494410404800204

Hammerness, K. (2006). From coherence in theory to coherence in practice. Teachers College Record, 108(7), 1241-1265. https://doi.org/10.1111/j.1467-9620.2006.00692.x

Holdsworth, S., Wyborn, C., Bekessy, S., \& Thomas, I. (2008). Professional development for education for sustainability. International Journal of Sustainability in Higher Education, 9(2), 131-146. https://doi.org/10.1108/14676370810856288

Kerscher, U. (2019). Towards a Sustainable Future? The EU Policies Concerning Plastics and Their Didactical Potential for Primary and Secondary Teaching. Discourse and Communication for Sustainable Education, 10(1), 47-62. https://doi.org/10.2478/dcse-2019-0005

King, N. (2004). Using templates in the thematic analysis of text. In C. Cassell \& G. Symon (Eds.), Essential guide to qualitative methods in organizational research (pp. 257-270). London, UK: Sage.

Le Cornu, R., \& Ewing, R. (2008). Reconceptualising professional experiences in pre-service teacher education... reconstructing the past to embrace the future. Teaching and Teacher Education, 24(7), 1799-1812. https://doi.org/10.1016/j.tate.2008.02.008

Lysgaard, J. A., \& Simovska, V. (2016). The significance of 'participation' as an educational ideal in education for sustainable development and health education in schools. Environmental Education Research, 22(5), 613-630. https://doi.org/10.1080/13504622.2015.1029875

Maidou, A., Plakitsi, K., \& Polatoglou, H. M. (2016). Perceptions and attitudes of students towards education for sustainable development. In J. Lavonen, K. Juuti, J. Lampiselkä, A. Uitto \& K. Hahl (Eds.), Electronic Proceedings of the ESERA 2015 Conference. Science education research: Engaging learners for a sustainable future, Part 9 (co-ed. Marianne Achiam \& Graça Carvalho), (pp. 1366-1377). Helsinki, Finland: University of Helsinki. ISBN 978-951-51-1541-6

Maidou, A., Plakitsi, K., \& Polatoglou, H. M. (2019a). Knowledge, Perceptions and Attitudes on Education for 
Sustainable Development of Pre-Service Early Childhood Teachers in Greece. World Journal of Education, 9(5), 1-15. https://doi.org/10.5430/wje.v9n5p1

Maidou, A., Plakitsi, K., \& Polatoglou, H. M. (2019b). Socrates' house: A suitable paradigm to introduce pre-service teachers to Education for Sustainable Development. In F. Seroglou and V. Koulountzos (Eds.), Proceedings of the 15th International History, Philosophy and Science Teaching Conference, Re-introducing science: Sculpting the image of science for education and media in its historical and philosophical background, (pp. 348-361). Thessaloniki, Greece: Grafima Publications.

Maidou, A., Plakitsi, K., \& Polatoglou, H. M. (2020). Using houses to introduce students to Education for Sustainable Development. Submitted for publication.

McKeown, R. (2002). Education for sustainable development toolkit. Retrieved from http://www.esdtoolkit.org/

McKeown, R. (2014). The Leading Edge of Teacher Education and ESD. Journal of Education for Sustainable Development, 8(2), 127-131. https://doi.org/10.1177/0973408214548366.

McKeown, R., \& Hopkins, C. (2003). EE $\neq$ ESD: Defusing the worry. Environmental Educational Research, 9(1), 117-128. https://doi.org/10.1080/13504620303469

McNaughton, M. J. (2012). Implementing Education for Sustainable Development in Schools: Learning from Teachers' Reflections. Environmental Education Research, 18(6), 765-782. https://doi.org/10.1080/13504622.2012.665850

Mochizuki, Y., \& Bryan, A. (2015). Climate Change Education in the Context of Education for Sustainable Development: Rationale and Principles. Journal of Education for Sustainable Development, 9(1), 4-26. https://doi.org/10.1177/0973408215569109

Murray, J., McNamara, O., \& Jones, M. (2014). Improving Workplace Learning in Teacher Education. In O. McNamara, J. Murray, \& M. Jones (Eds.), Workplace Learning in Teacher Education: International Practice and Policy. (pp 293-315). Dordrecht: Springer. https://doi.org/10.1007/978-94-007-7826-9

Nowell, L. S., Norris, J. M., White, D. E., \& Moules, N. J. (2017). Thematic Analysis: Striving to Meet the Trustworthiness Criteria. International Journal of Qualitative Methods, 16(1), 1-13, https://doi.org/10.1177/1609406917733847.

Patrick, R. (2013). "Don't rock the boat": conflicting mentor and pre-service teacher narratives of professional experience. The Australian Educational Researcher, 40, 207-226. https://doi.org/10.1007/s13384-013-0086-z

Postholm, M. B. (2015) Methodologies in Cultural-Historical Activity Theory: The example of school-based development. Educational Research, 57(1), 43-58. http://dx.doi.org/10.1080/00131881.2014.983723

Pridham, B. A., Deed, C., \& Cox, P. (2013). Workplace-Based Practicum: Enabling Expansive Practices. Australian Journal of Teacher Education, 38(4), 50-64. https://doi.org/10.14221/ajte.2013v38n4.7

Rantavuori, J., Engeström, Y., \& Lipponen, L. (2016). Learning actions, objects and types of interaction: A methodological analysis of expansive learning among pre-service teachers. Frontline Learning Research, 4(3), 1-27. https://doi.org/10.14786/flr.v4i3.174

Rorrison, D. (2006). Turning a critical lens on the practicum in secondary pre- service teacher education programs. In P. L. Jeffery (Ed.), AARE2005: Creative Dissent: Constructive Solutions, (pp. 1-30). Melbourne, Australia: AARE.

Roth, W.-M., Lawless, D., \& Tobin, K. (2000). \{Coteaching | cogenerative dialoguing\} as praxis of dialectic method. Forum Qualitative Sozialforschung/ Forum Qualitative Social Research, 1(3). Retrieved from http://www.qualitative-research.net/index.php/fqs/article/viewArticle/1054/2283

Roulston, K. (2001). Data analysis and 'theorizing as ideology'. Qualitative Research, 1(3), 279-302. https://doi.org/10.1177/146879410100100302

Saka, A., \& Sahintürk, A. (2013). Attitudes of prospective forest engineers and primary school teachers towards a sustainable environment. Polish Journal of Environmental Studies, 22(50), 1533-1557.

Smagorinsky, P., Cook, L. S., Moore, C., Jackson, A. Y., \& Fry, P. G. (2004). Tensions in learning to teach: Accommodation and the development of a teaching identity. Journal of Teacher Education, 55(1), 8-24. https://doi.org/10.1177/0022487103260067

Smith, K., \& Lev - Ari, L. (2005). The place of the practicum in pre - service teacher education: The voice of the 
students. Asia-Pacific Journal of Teacher Education, 33(3), 289-302. https://doi.org/10.1080/13598660500286333

Sorensen, P. (2014). Collaboration, dialogue and expansive learning: The use of paired and multiple placements in the school practicum. Teaching and Teacher Education, 44, 128-137. http://dx.doi.org/10.1016/j.tate.2014.08.010.

Sterling, S. (2010). Learning for resilience or the resilient learner? Towards a necessary reconciliation in a paradigm of sustainable education. Environmental Education Research, 16(5), 511-528. https://doi.org/10.1080/13504622.2010.505427

Summers, M., Corney, G., \& Childs, A. (2003). Teaching Sustainable Development in Primary Schools: An Empirical Study of Issues for Teachers. Environmental Education Research, 9(3), 327-346. https://doi.org/10.1080/13504620303458

Tomas, L., Girgenti, S., \& Jackson, C. (2017). Pre-service teachers' attitudes toward education for sustainability and its relevance to their learning: implications for pedagogical practice. Environmental Education Research, 23(3), 324-347. https://doi.org/10.1080/13504622.2015.1109065

Trent, J., \& Lim, J. (2010). Teacher identity construction in school-university partnerships: Discourse and practice. Teaching and Teacher Education, 26(8), 1609-1618. https://doi.org/10.1016/j.tate.2010.06.012

UNESCO. (1992). United Nations Conference on Environment and Development: Agenda 21. UNESCO: Switzerland.

UNESCO. (2005a). Guidelines and Recommendations for Reorienting Teacher Education to Address Sustainability. Paris: UNESCO.

UNESCO. (2005b). United Nations decade of education for sustainable development (2005-2014): International implementation scheme. Paris: UNESCO.

UNESCO. (2012). Education for Sustainable Development in Action. Paris: UNESCO.

Virkkunen, J., \& Kuutti, K. (2000). Understanding organizational learning by focusing on 'activity systems'. Accounting. Management and Information Technologies, 10(4), 291-319. https://doi.org/10.1016/S0959-8022(00)00005-9

Waring, R. H., Harris, R. M., \& Mitchell, S. C. (2018). Plastic contamination of the food chain: A threat to human health? Maturitas, 115, 64-68. https://doi.org/10.1016/j.maturitas.2018.06.010

White, S., \& Forgasz, R. (2016). The Practicum: The Place of Experience? In J. Loughran \& M. L. Hamilton (Eds.), International Handbook of Teacher Education. (pp 231-265). Singapore: Springer. https://doi.org/10.1007/978-981-10-0366-0_6

White, S., Bloomfield, D., \& Le Cornu, R. (2010). Professional experience in new times: Issues and responses to a changing education landscape. Asia-Pacific Journal of Teacher Education, 38(3), 181-193. https://doi.org/10.1080/1359866X.2010.493297

Wiek, A., Withycombe, L., Redman, C., \& Banas Mills, S. (2011). Moving forward on Competence in Sustainability Research and Problem Solving. Environment, 53(2), 3-12. https://doi.org/10.1080/00139157.2011.554496

Wilson, S. M., Floden, R. E., \& Ferrini-Mundy, J. (2002). Teacher preparation research an insider's view from the outside. Journal of Teacher Education, 53(3), 190-204. https://doi.org/10.1177/0022487102053003002

World Commission on Environment and Development (WCED). (1987). Our common future. Oxford: Oxford University Press.

Xenophon. (1923). Memorabilia. Translated by E. C. Marchant. Cambridge, MA: Harvard University Press. Retrieved from http://www.perseus.tufts.edu/hopper/text?doc=Perseus\%3Atext\%3A1999.01.0208\%3Abook\%3D3\%3Achapter $\% 3 \mathrm{D} 8 \% 3$ Asection\%3D8. 